\title{
La relación entre biotecnología y progreso como "valores indiscutidos". Sus implicancias éticas y políticas
}

María Luisa Pfeiffer'

Universidad de Buenos Aires

Artículo de Reflexión derivado de Investigación.

Recibido: septiembre 24 de 2015 - Aprobado: octubre 21 de 2015

\section{Resumen}

La ética, como praxis debe crear espacios de convivencia que permitan descubrir cuál es la característica de los espacios de dominación en que habitamos y tratar de construir otros donde los hombres y los pueblos puedan vivir libremente su destino. El planteo de este trabajo es que, en América Latina, el espacio biotecnológico debido a que es una gran fuente de ambigüedades cuando de valores se trata, termina siendo aliado de los poderes dominantes. Se analiza especialmente esa característica en el uso de la ingeniería genética para la transformación de semillas, mostrando que si bien por un lado se puede considerar a la misma como una resultante valiosa de la ciencia, por el otro resulta dañina no sólo en lo relativo a la conservación de la vida con toda su diversidad, sino en lo económico, social, cultural, antropológico e incluso médico. El propósito final del trabajo es una reflexión sobre el mito del progreso asociado al crecimiento de la biotecnología y la necesidad de establecer límites éticos al mismo.

Palabras clave: Biotecnología, tecnociencia, progreso, transgénicos, América Latina.

I Doctora en Filosofía (Sorbonne), Investigadora en Bioética en el Consejo Nacional de Investigaciones Científicas y Técnicas de la República Argentina. Dirección electrónica: Maria3729@hotmail.com 


\title{
The relationship between biotechnology and progress as "unquestioned values", its ethical and political implicatures
}

\begin{abstract}
Ethics, as praxis, must create spaces for coexistence that allow us to discover what is the characteristic of the domination spaces we live in, as well as to create others where individuals and peoples can live their destiny in a free way. This paper states that in Latin America, given that it is a source of ambivalence when thinking about values, biotechnology ends up being an ally of the dominant powers. This characteristic is specially analyzed in the use of genetic engineering for seed transformation, showing that, even though it can be considered as a valuable result of science, on the other hand it is hazardous not only in regards to conservancy of life in all its diversity, but also in economic, social, cultural, anthropological, and even, medical respects. The final aim of the paper is to stimulate a reflection about the myth of progress associated to the growth of biotechnology, and to state the need to establish ethical limits to it.
\end{abstract}

Key words: biotechnology, techno-science, progress, transgenic, Lain America

\section{A relação entre biotecnologia e progresso como "valores indiscutidos", suas implicações éticas e políticas}

\begin{abstract}
Resumo
A ética, como práxis, deve criar espaços de convivência que permitam descobrir qual é a característica dos espaços de dominação em que habitamos e tratar de construir outros onde os homens e os povos possam viver livremente seu destino. $O$ foco deste trabalho é que na América Latina o espaço biotecnológico devido a que é uma grande fonte de ambiguidades quando de valores se trata, acaba sendo aliado dos poderes dominantes. Analisa-se especialmente essa característica no uso da engenharia genética para a transformação de sementes, mostrando que se bem por um lado se pode considerar a mesmo como uma resultante valiosa da ciência, pelo outro resulta danosa não só no relativo à conservação da vida com toda sua diversidade, mas no econômico, social, cultural, antropológico e até no médico. $\bigcirc$ propósito final do trabalho é uma reflexão sobre o mito do progresso associado ao crescimento da biotecnologia e à necessidade de estabelecer limites éticos ao mesmo.
\end{abstract}

Palavras chave: Biotecnologia, tecnociência, progresso, transgênicos, América Latina.

\section{Introducción}

La reflexión ética no puede hacerse desde "ningún tiempo y ningún lugar", sino que debe considerar las situaciones y la vida de la gente. Plantear la ética como una teoría no hace más que acentuar la confu- 
sión que permite que ella esté ausente de la vida cotidiana. La ética es una praxis en el sentido en que los griegos utilizaban ese término, es decir un hacer creador, un arte. ¿Y qué es lo que crea? Espacios de convivencia. Hay ciertas condiciones a cumplir al constituir esos espacios: la libertad es una de ellas, la justicia es la otra. El resultado será un espacio político. Para entendernos, cuando hablamos de ética tenemos que ubicarnos en un terreno común, en un espacio inter, un entre, en un ámbito común. La pregunta que debemos hacer, precisamente para no pensar la "comunidad" de los convivientes fuera del tiempo y del espacio, es qué papel juega el poder entre esos convivientes, quién lo ejerce, para qué es ejercido y sobre todo cómo evitar que adquiera la forma que impide y aleja de la convivencia, cual es la dominación. La dominación es un entre que no une sino que separa, organizado espacialmente como orden jerárquico, en que unos están arriba y otros abajo. Toda reflexión ética que genere una práctica política, nace de la demanda de evitar la dominación y va "edificando" un espacio horizontal, donde las prácticas constituyen, definen, organizan e instrumentalizan estrategias que posibiliten a los individuos libres relacionarse como iguales, como semejantes, como "hermanos". ${ }^{2}$ Esto dará pie al reconocimiento participativo de valores coincidentes, de fines compartidos, de medios comunes.

En la actualidad, existe un espacio, el del denominado progreso biotecnológico, donde se encuentra la mayor fuente de ambigüedades cuando de valores se trata y lo que nos interesa es saber si es posible calificarlo como lugar inter de los humanos y no humanos o más bien se trata de un espacio de poder. Progreso y tecnología (biotecnología especialmente) no pueden separarse en el imaginario del hombre actual y parecen ser las únicas dos coordenadas inevitables a la hora de construir espacios políticos, aunque también sean las más dilemáticas. Ni la ética ni la política pueden aceptar que la tecnología y el progreso sean valores indiscutibles, principios de acción que adquieran carácter de imperativo apriorístico, la única finalidad aceptada o aceptable para una filosofía de la historia. Al constituir un supuesto necesario en el imaginario de la sociedad latinoamericana actual, ni la política ni la ética puede ignorar que el progreso biotecnológico es el supuesto que cimenta la exigencia de una acción mancomunada de los pueblos para conquistar un futuro mejor. Tampoco pueden negar su vigencia en América Latina, ni el hecho de que se haya transformado en la nueva moira de la historia latinoamericana.

Esto nos obliga a preguntarnos: ¿Cuál es el precio que América Latina, o mejor la humanidad está dispuesta a pagar por un progreso con estas características? Hay cuestiones ineludibles a resolver frente a esta razón tecnocientífica cuya única referencia es la utilidad, ${ }^{3}$ y que tiene en la biotecnología su expresión más cabal. Una de ellas que exige una reflexión ética es, si todo lo que se puede hacer debe hacerse. Para responderla habrá que establecer el rol que juegan en el armado de este imaginario, en ese entre que estamos proponiendo, los políticos, los científicos, los tecnócratas, los tecnólogos, los profesionales en general sino, sobre todo por las características utilitarias de la tecnociencia de las empresas. También sobre el lugar que ocupará cada uno de ellos frente a la comunidad

2 Pensemos en la demanda de fraternidad de la Revolución Francesa que reclamaba también libertad e igualdad.

3 "Esbozo y rigor, procedimiento y empresa fomentándose recíprocamente, constituyen la esencia de la ciencia moderna", Heidegger, M., Sendas Perdidas, "La época de la imagen del mundo" (capítulo), Losada, Bs. As., 1960. 
de intereses, ya que habrá que decidir cuáles son los que se priorizan si los de los empresarios, los de los tecnocientíficos, los de los grandes capitales sustentadores económicos del "progreso" o los de la población. Por ello es necesario mostrar no sólo cómo las coordenadas ciencia - progreso se han cruzado desde sus orígenes con la variable poder, sino que esa relación se da en grado superlativo en el ámbito de la biotecnología donde la modalidad crematística, los intereses monetarios, han incidido definitivamente en su nacimiento y espectacular desarrollo. No es la primera vez que la investigación científica y el uso de sus resultados se ve como amenaza, tal vez esto no sea sino un momento del proceso dialéctico de apropiación del conocimiento. Sin embargo, cabría preguntarse ¿qué tiene de nuevo este fenómeno, sobre todo en sus manifestaciones en América Latina?

\section{Ciencia y progreso}

La biotecnología ha avanzado porque nuestra cultura sigue presa del mito de la ciencia y del progreso y es imposible criticar a los mitos desde la racionalidad. ${ }^{4}$ Podemos analizar hipótesis, leyes, ideas, pero no mitos, porque estos son del orden de las creencias. La ciencia y la técnica "han asumido la inhabilidad otrora reservada a la religión y por lo tanto para la civilización industrial se han constituido no sólo en conocimiento e institucionalización del mismo sino en marco de legitimidad". ${ }^{5}$ La palabra progreso comienza a escribirse con mayúscula a partir del siglo XVIII y su prestigio aumenta paralelamente al crecimiento de la ciencia. Ambas constituyen el matrimonio ideal en el imaginario de nuestra cultura. Su sustento es una filosofía de la historia que nace a partir del Renacimiento, cuando los filósofos comienzan a considerar el movimiento como algo digno de ser pensado por un lado y por otro a consolidar la independencia de un pensamiento hasta entonces sujeto a la providencia divina, como era el medieval. ${ }^{6}$ En este siglo, empieza a percibirse a la historia como cambio lineal, en oposición a su concepción como movimiento circular que obedecía a una concepción estática que formaba parte del corazón de la filosofía griega, y que el cristianismo nunca pudo aceptar. ${ }^{7}$ La historia como progreso comienza a tomar

4 Ladrière hace una interesante observación que confirma aún más el peso mitológico de la ciencia sobre la opinión pública. afirma que las características con que se presenta la ciencia contemporánea "se conjugan para mostrar al hombre de ciencia como una especie de demiurgo, que maneja fuerzas temibles, dotado de poderes casi sobrenaturales, pero que tiene también el riesgo de ser devorado en cualquier momento por los poderes mágicos que él ha desencadenado". El carácter ambivalente de los personajes míticos en que se conjuga el bien y el mal, que son a la vez admirados y temidos está presente en la ciencia y sus cultores. Ladrière, Jean, El reto de la racionalidad, UNESCO, París, 1997.

5 Para algunos filósofos como Lakatos la ciencia no es una creencia en cuanto que ésta es indiscernible de los contextos socioculturales, es decir de su génesis social y de los ámbitos de práctica social, todo en la creencia es reductible a "vida externa", en cambio para él la ciencia tiene "vida interna", es decir "tiene un lógica propia, un impulso interno propio, autónomo de los procesos sociales". Esto ha sido negado por Kuhn y Feyerabend. "El primero al considerar la ciencia como estereotipo, el segundo al considerarla como mito". Pavón Rodríguez, Manuel, "El problema de la interacción entre ciencia, tecnología, y sociedad. Una consideración crítica del campo de la CTS”, Argumentos de razón técnica, NI, 1998, págs. 124-125.

6 Pfeiffer, María Luisa, El espacio de la desmesura. Una aproximación bioética a la moral, Antropofagia, Buenos Aires, 20 I4, en prensa.

7 El origen de la concepción progresiva de la historia proviene de dos ideas fundantes del judeo-cristianismo: el tiempo lineal asociado al concepto de creación y el fin de la historia profana expresada en términos de juicio y salvación. En los primeros filósofosteólogos cristianos, el más claro ejemplo de ello es San Agustín, vemos grandes contradicciones en el desarrollo de sus filosofías que provienen de la enorme dificultad en conciliar dos concepciones de la historia tan disímiles: la griega en que el final coincide con el principio en un círculo perfecto, una filosofía cuya mayor preocupación es alcanzar la quietud del equilibrio, y la judía en 
cuerpo luego de la famosa querelle des anciens et des modernes (querella entre antiguos y modernos) de principios del S XVIII, que fue desarrollada apasionadamente por más de un siglo. Poco a poco la religión del progreso se va apoderando de los espíritus y las inteligencias, dejando sentado que el proceso histórico es interrumpido por continuas mutaciones de lo bueno hacia lo mejor y oponiéndose a cualquier concepción circular o estática de la historia ${ }^{8}$ e incluso a concepciones regresivas para las cuales la mutación era de lo malo hacia lo peor, como la platónica. ${ }^{9}$

La concepción de la vida que explota en la modernidad y que viene gestándose a lo largo de todo el medioevo, piensa encontrar un remedio a los males del hombre trabajando sobre la naturaleza. La posibilidad de la técnica tiene su origen en el concepto de salvación. La acción de un hombre (Cristo lo es) sobre la historia con el propósito de salvar al ser humano del imperio del mal, juega el rol de una terapéutica ontológica. Esto había sido también planteado por los griegos con la idea de la salud prometeica alcanzada por las obras y por los frutos del árbol del conocimiento, pero el mito griego se inserta en el imperio de la desmesura, de la hybris que exige, tarde o temprano, ser punida. Si bien puede leerse el primer relato bíblico con un sentido semejante al mito prometeico, existe una diferencia fundamental que es la promesa de redención del pecado por una intervención divina en la historia hacia la que "marcha" el pueblo. El futuro de la salvación será mejor que el presente del pecado. Hay un fin de la historia, fin como meta y como acabamiento. Sólo a partir de la vivencia, inherente a la cultura judeocristiana e ignorada por los filósofos griegos, será posible aceptar el rango creador del hombre y mucho más tarde asociar esto al progreso. El paso no fue fácil, todavía Santo Tomás de Aquino habla del "adulterinus intellectus" refiriéndose a un saber que se consagra a producir obras artificiales que buscan transformar la naturaleza olvidándose de contemplarla. ${ }^{10}$

que el cambio es constitutivo de su razón de ser. Esto último se ve en la Biblia, que es el relato de un movimiento incesante en la búsqueda de la tierra prometida, un proceso indefinido de búsqueda de Dios. Para la antigüedad clásica el curso de la historia no parecía en absoluto un curso, sino una sucesión cíclica de fases idénticas, que no llegaba a experimentar nunca una nueva transformación. Por el contrario el tiempo judeo-cristiano es lineal y su concepción de la historia es progresiva, marcha hacia el momento en que el Mesías intervendrá en ella; el tiempo griego es circular, al modo del tiempo de otros pueblos de Oriente y lo que parece ser una marcha histórica, un avance hacia algún lugar, es simplemente re-encontrarse en el principio y recuperar la quietud. Frente al desafío que representa la construcción de la cultura separada de la naturaleza, los griegos mantienen una actitud contemplativa donde la praxis humana consiste básicamente en conocer el lugar del hombre en el cosmos, en lo que Foucault denomina "cuidado de uno mismo" y cuyo resultado más consecuente es el estoicismo, es decir mantenerse alejado de todo aquello que pueda provocar o acrecentar el dolor. Ibidem.

8 Una de las cuestiones discutidas en la filosofía de Hegel es precisamente el carácter que asume en ella la temporalidad.

9 Pero además esa regresión de la historia no formaba parte de un movimiento continuo, sino cíclico de modo que el movimiento en realidad no existía.

I0 La pregunta es si la contradicción a que nos somete la presencia significativa de un tiempo que ha comenzado y va a terminar, ha sido resuelta más allá de haber originado el gran mito del progreso. Conciliar las dos visiones de la historia representó un problema imposible de resolver para los teólogos medievales, profundamente influidos por la filosofía platónica. La fuerte opción por la ciencia que se da en el Siglo XVIII asociada al dinamismo del progreso, es un intento de "superarlo", sin embargo la dificultad vuelve a aparecer con gran fuerza en el siglo XX y actualmente, cuando la ciencia pierde el escudo mítico que la protegía En su obra La nueva Alianza, llya Pregogine cita lo que Albert Einstein expresó ante la muerte de un amigo "Para nosotros físicos convencidos, el tiempo es tan sólo una ilusión, aunque sea tenaz" (pág.263). Prigogine hizo girar toda su obra sobre el tiempo. Para él "los cambios reversibles son un caso límite en los cuales la naturaleza tiene tanta propensión hacia el estado inicial como hacia el estado final; por eso el paso del uno al otro es posible en los dos sentidos" (pág. I 27) En el universo planteado por los metafísicos modernos "...el mundo no sería más que una inmensa tautología eterna y arbitraria, tan necesaria y absurda en cada 
Luego de la que podríamos llamar revolución científica, en que aparece un tipo de conocimiento capaz de permitir al humano actuar sobre la naturaleza y transformarla sin que ello sea pecado, luego de los descubrimientos geográficos y antropológicos que extienden los límites de lo humano, abriendo nuevas esperanzas a la afirmación del regnum hominis, el movimiento primero y el progreso después, adquieren carácter de bienes indiscutibles. En un mundo en que ya no se escucha la voz de ninguna divinidad, la voluntad quiere transgredir todos los límites llevando al extremo todas sus posibilidades, y encomienda esa tarea a la ciencia. Es así que ésta adquiere peso histórico a partir del Renacimiento. Recordemos que este período de la historia es incubado por la propuesta teológica denominada Reforma, " la cual es valorada por todos aquellos que la siguen y promueven, no sólo como buena sino como mejoradora del orden anterior. Comienza allí a forjarse una idea acerca de cualquier período posterior al actual y que se sigue conservando: la de que el futuro será mejor que el pasado. Esto arraiga en la cultura occidental como una comprensión de la historia como una continuidad progresiva, evolutiva, superadora, perfectible. ${ }^{12}$ La valoración positiva de la Reforma Protestante es el punto de arranque de que conceptos como cambio, renovación, evolución, reforma, revolución sean aceptados como buenos en sí mismos y que las realidades a que aluden sean deseadas. ${ }^{13}$ Lo que está a la base de la búsqueda de renovaciones, revoluciones y reformas es una concepción de la historia dominada por la idea de la bondad del movimiento y la inevitabilidad del progreso, ${ }^{14}$ es decir la concepción evolutiva de la historia que permite rechazar hoy, por ejemplo, la clasificación política de derecha e izquierda, liberal y socialista, para dividir el mundo en dinámicos y estáticos: los primeros serían los que dan la bienvenida al futuro y los segundos los que quieren parar el movimiento progresivo, volver hacia atrás o regular el cambio. Además de un tipo de clasificación, esto implica una valoración: nadie querría ser calificado de regresivo o retrógrado. Notamos esta valoración en la utilización política habitual de calificativos para la ideología opositora: para los liberales los que no comulgan con sus ideas son conservadores, para los socialistas son reaccionarios. ${ }^{15}$

El crecimiento de la valoración del progreso viene unido a dos acontecimientos: la incorporación del tiempo como variable a considerar en el pensamiento filosófico y el desarrollo de la ciencia. Uno de

uno de sus detalles como en su totalidad. Tal es el desafío de esta ciencia moderna que nos ha legado el siglo XIX y que nos es necesario exorcizar hoy". (pág. 84) Para Prigogine el tiempo no puede ser únicamente lineal, "la historia, sea la de un ser vivo, - la de una sociedad, no podrá jamás ser reducida a la sencillez monótona de un tiempo único, (esta idea) ha sido reemplazada por una complementariedad que nos queda por comprender". (pág. 263) La Nueva Alianza, Alianza Ed, .Madrid, 1983.

II Especialmente el calvinismo por su acentuación del carácter ético de la vida y la concepción de la existencia como actividad y cuidado. Ver Aranguren, José Luis, El protestantismo y la moral, Ed. Sapientia, Madrid, 1954.

12 Esto tiene una relación directa con el auge siempre renovado de las teorías evolutivas aplicadas a la ciencia y la sociedad de Darwin, Lamark y Spencer principalmente.

13 No podemos ignorar que el presente histórico está marcado por la valoración del cambio y del movimiento, y que gracias a la globalización económica esto ha contaminado otras culturas del planeta.

I4 Reforma y revolución se distinguen por la diferente manera en que conciben el primero e interpretan el segundo, sea como movimiento continuo o con saltos.

I5 Es interesante marcar que sin embargo existen ciertos signos de revisión de este proceso. Por ejemplo algunos sitios de Internet como el denominado "Old Version.com" cuyo lema es "Porque lo nuevo no siempre es lo mejor", donde se ofrecen distintas versiones de ciertos programas informáticos, mostrando que los más antiguos pueden tener ventajas sobre los más actuales por el hecho de ser más livianos, simples o fáciles de operar. 
los mayores responsables de la asociación progreso-ciencia es Comte (I 798- I 857) quien la consideró como el ideal moral de la Humanidad, el bien supremo. Al igual que Hegel, ${ }^{16}$ Comte está convencido de que ningún fenómeno puede entenderse filosóficamente a menos que lo sea históricamente: mediante una demostración de su destino y derivación temporales, de su función y significado. Lo que muchas veces parece contradictorio, caótico, no es más que la expresión de una continua evolución dirigida a un fin. ${ }^{17}$ Su obra Cours de philosophie positive (Curso de filosofía positiva) presenta la marcha fundamental del desarrollo humano y el progresivo derrotero del espíritu humano, dirigiéndose a la etapa científica, como la de madurez. El progreso y el perfeccionamiento provienen del desarrollo asociado al conocimiento científico. Esta creencia de Comte en el positivismo progresivo "no es compartida en la actualidad, por "las mejores mentes" del Viejo Mundo, -según una expresión de Löwith- pero está en boga todavía en el Nuevo, cuyas constituciones son el producto de las creencias del siglo XVIII". ${ }^{18}$ Un ejemplo revelador de esto es el lema de la República del Brasil que figura en su bandera: "orden y progreso". Esta es una expresión acuñada por Comte que afirma: "“.'Ningún orden real se puede establecer más, ni sobre todo durar, si no es plenamente compatible con el progreso; ningún gran progreso podría efectivamente realizarse si no tiende finalmente a la evidente consolidación del orden". ${ }^{19}$ Ambos, orden y progreso, deben ser promovidos, guiados y consolidados por la ciencia y serán obtenidos como producto acumulativo de pequeños, quizás imperceptibles cambios para mejorar. La cultura occidental crece aceleradamente adhiriendo a esta creencia como a una especie de religión laica, que es alentada por el sueño burgués de lograr una humanidad mejor. Los científicos de esa época son los que añoramos hoy, que, según la descripción que hace Sábato y que por su interés citaré entera, "creen en la unificación de los hombres mediante la ciencia, olvidando su costado destructivo", se horrorizan "ante los efectos de la bomba atómica -que al fin de cuentas ha sido inventada por ellos- y preconizan la unión de los pueblos a base de tolerancia y bienestar colectivo... Pero estos cándidos sabios, agrega Sábato, son más eficaces en la fabricación de la bomba que en la realización de esa utopía, donde al parecer el lobo estaría al lado del cordero escuchando una clase de electrónica. Esos sabios son los últimos ejemplares de esa paradojal religión mundana, que también ha tenido su fariseísmo y su clericalismo... Lo más sorprendente, es que durante tanto

16 La lectura del progreso de Hegel sin embargo es profundamente diferente de la de Comte. Aunque ambas tienen sus raíces en la concepción optimista de la razón del lluminismo, la hegeliana realiza una restricción de la misma, reinterpretando la concepción de la tradición teológica por la cual el tiempo ha sido ya consumado. Su utilización del principio racional del progreso no es revolucionaria sino conservadora. El progreso se dirige hacia una consumación y elaboración finales del principio establecido del entero curso de la historia. Esto va en contra del planteo de Comte que es evolutivo.

17 Ambos autores consideran explícitamente que esa evolución tiene como protagonista a la raza blanca y el occidente cristiano. Para Hegel esta prerrogativa es resultado de la calidad de la filosofía racionalista occidental, para Comte de la superioridad física, química y biológica de la raza blanca. Ver Comte, A., Cours de Philosophie Positive, 6 T., Bachelier, Paris, I830-1842.

18 Löwith, Karl, El sentido de la historia, Aguilar, Madrid, 1968, pág. 106.

19 Comte, A., id. T.IV, leçon 46, pág. 8.

Comte considera que luego de las revoluciones sufridas por occidente, la ciencia debe hacer su parte para reestablecer y reorganizar la fuerza estabilizadora del orden. "Sólo un sistema que armonice orden y progreso puede encauzar al estado revolucionario que ha sido característico de la historia europea desde la disolución del orden medieval, hacia una meta final y progresiva". Los fundadores de Brasil sin duda concibieron el futuro a la luz de este postulado positivista acerca de que la combinación de orden y progreso es el principio y "el origen primordial de todo genuino sistema político". 
tiempo se haya podido creer en esta religión. Es fácil, en efecto, probar la superioridad del avión sobre la carreta, pero ¿cómo demostrar el progreso moral o político?...Comte -sigue diciendo Sábato- fue el inventor de la palabra altruismo, e imaginó que las guerras se harían más raras con el avance de la ciencia y que la industria aseguraría la paz y la felicidad universales". 20

Adopto con Sábato, la actitud del escéptico contra una lectura de la historia que permite hablar ingenuamente de progreso como se hacía en los siglos XVII y XVIII: como avance indefinido hacia "más y más racionalidad, más y más libertad y más y más felicidad". Lo primero a tener en cuenta es que lo que llamamos progreso tiene que ver con el orden social, por consiguiente no depende sólo de los conocimientos científicos y técnicos sino que requiere una determinada capacidad social de apropiarse de los resultados y convertirlos en políticas que beneficien a las poblaciones. No es cuestionable en general la relación progreso-ciencia como positiva a la hora de pensar la integración social de los bienes que puede originar, el problema es que la ciencia, como paradigma del conocimiento, alcanza a partir de esa relación un auténtico protagonismo. En ese sentido, el cuestionamiento a una concepción ingenua del progreso debe alcanzar también a la ciencia, porque ninguno de los dos cumplieron con su promesa de hacer a los hombres más buenos, más libres, más felices.

Tal vez hoy más que nunca tiene sentido volver a preguntarnos si debemos poner en práctica todo lo que nuestra imaginación nos proponga y la técnica nos permita o si habrá que ponerles algún límite. No todo lo científicamente posible es éticamente aceptable.

\section{Crecimiento biotecnológico}

No es sencillo cuestionar a la ciencia porque no existe un lugar legítimo desde donde podamos hacerlo en tanto y en cuanto todos de alguna manera somos fieles de la religión de la que habla Sábato. Sin embargo hoy es fuertemente controvertido la dependencia que sufre la ciencia respecto de la tecnología, es ésta la que establece las prioridades y necesidades a la investigación científica. Sobre todo es criticado que dependa de la biotecnología, que, como manifestación utilitaria del espíritu científico, es la más fuertemente cuestionada sobre todo por la creciente sensación de riesgo al que nos somete. El riesgo que estamos afrontando es el de sujetar las leyes de la vida a la voluntad humana. Muchas veces asociamos esa sujeción a deseos individuales, sin embargo éstos no pueden ser llevados a cabo sin la aprobación, aunque sea implícita de una sociedad y una cultura, más aún de una política, ${ }^{21}$ por lo que lo que nos pone en riesgo real no son decisiones locas de individuos caprichosos sino decisiones sociales que se concretizan en políticas públicas y privadas. El riesgo que percibimos nos afecta como seres humanos pero sobre todo como seres vivos habitantes de un planeta en jaque. El cuestionamiento a una técnica que manipula la vida, puede hacerse desde dos modos de establecer las relaciones entre

20 Sábato, E., Hombres y engranajes, Emece, Buenos Aires, 1970, pág.75.

21 Recordemos la calificación de empresa que hace Heidegger a la que ya nos hemos referido, cuando afirma que la ciencia moderna no solamente busca utilidades sino que necesita de capital para poder desarrollarse. Y esta dependencia es cada vez peor por la complejidad de la infraestructura que necesita hoy el desarrollo científico. 
la tecnociencia, la sociedad y la naturaleza: se puede llegar a imaginar a la tecnociencia como una caja de útiles metida dentro de la caja social en cuyo caso el peso de las decisiones comunes establecería su derrotero y su sentido, ${ }^{22}$ o se puede considerar que ambas: tecnología y sociedad, están metidas dentro de la caja natural (la biosfera) y que, por consiguiente, la voluntad común debe ajustarse a un orden no establecido por ninguna de las dos sino que las implica. ${ }^{23}$ La respuesta en cualquiera de estos dos casos sería la aceptación de un orden: el natural o el social, como regulador de la práctica biotecnológica. Sin embargo, aquello con que nos topamos, como fenómeno preponderante, es que los desarrollos actuales de la tecnología, especialmente los de la biotecnología, parecen querer establecer autónomamente sus pautas de crecimiento, lo cual genera un desafío a ambos órdenes: el natural y el social. El proyecto originario de la biotecnología que vemos en la actualidad elevarse a altísima potencia, es lograr vencer las barreras que pone la naturaleza a ciertos intereses, pero además, sus "logros" se imponen hoy, también, al orden social, y la muestra de ello la tenemos cuando éste acepta y responde a los criterios tecnológicos sin discusión. Otro indicio, no menos importante, es la generación de deseo por parte de la biotecnología, que atraviesa todo el campo simbólico y valorativo de la cultura. Ciertos "logros" o "avances" biotecnológicos instituyen de hecho conductas o procedimientos que son valorados positivamente debido a su procedencia y van generando la necesidad de establecer normas legales que los regulen antes de decidir acerca de su carácter beneficioso: uso de gametos para experimentación, tests genéticos, análisis preimplantatorios sin haber resuelto las bondades de ciertos implantes, terapias celulares no comprobadas científicamente, entre otros.

Por otra parte, dentro del ámbito científico, especialmente el que se dedica a la biología celular, o molecular, así como a la genética molecular, sigue vigente el supuesto de que puede existir una investigación "pura", "básica" que solamente mide fenómenos, y que no es responsable de las intervenciones que resulten de esas "mediciones". ${ }^{24}$ Esto da pie a que en determinados campos científicos se fomente ese tipo de investigación con total prescindencia de la resultante de las mismas como es el caso de la biología molecular que deriva hoy por ejemplo en estudios de neuroendocrinología molecular que se propone descubrir nuevos blancos para tratamientos farmacológico, lo cual está claramente promocionado por la industria.

Es posible citar aportes de la biotecnología valiosos para el mantenimiento de la vida y la salud como son la vacuna contra la hepatitis B, insulina humana, hormona de crecimiento (somatostatina),

22 Ver Maréchal, Jean-Paul, "L'écologie de marché, un mythe dangereux", Le Monde Diplomatique, october, 1966.

23 Muchas respuestas a la denominada cuestión ambiental, sobre todo aquellas que cuestionan el homocentrismo de la relación con la naturaleza se apoyan sobre este supuesto, ver Junges, R., "Sostenibilidad: Desarrollo sustentable y equidad", Rev.Redbioética/ UNESCO, Año 6, I (I l): enero-junio 20 I 5, Gudynas, E., 20 I4. Derechos de la Naturaleza. Etica biocéntrica y políticas ambientales, RedGE, PDTG, CooperAcción y CLAES, Lima; Pfeiffer, ML., "El deber moral de los estados y ciudadanos de preservar el mundo", Bioética, Conselho Federal de Medicina, Brasil, 20 I4; 22 (2), ISSN I983-8042/ 19838034: 203-2 I2 http://revistabioetica.cfm.org. br/index.php/revista_bioetica/article/view/910/1035

24 "Actualmente existe en Alemania una tendencia a decir que toda investigación debe acercarse al modelo Fraunhofer: "investigar a corto plazo para solucionar problemas concretos de la industria y la sociedad". Bosch, Joan, "Combinar investigación e innovación: el reto de los institutos Fraunhofer" en AAW, El papel de la ciencia básica para el desarrollo tecnológico: Repercusiones en los aspectos sociales y humanísticos, Alexander Von Humboldt Stifftung de España, Alcalá de Henares, 2007. 
proteína anticoagulante, realización de diagnósticos más certeros de algunas enfermedades; y otras que simplifican y multiplican la elaboración de ciertos productos como quimosina, ácido cítrico, degradantes del petróleo, la enzima celulasa como compactante, desteñidor de telas, la producción de detergentes y jabones, la facilitación de la extracción y filtración de jugos de frutas o verduras, mostos, aceites comestibles y la producción de combustibles.

En América Latina el acrecentar la denominada investigación pura es índice de desarrollo científico, de ninguna manera se lo considera apoyo a la biotecnología y su capacidad de dominio sobre la población. ${ }^{25}$ Es por ello que vemos que en nuestra región, y podemos agregar sin equivocarnos, en el mundo, la biotecnología va avanzando como un destino inexorable. Esto sucede a partir de la década del 80 en que aparece la bioingeniería o ingeniería genética, y actualmente con la biología y genética molecular y la bioinformática que permite utilizar técnicas computacionales para analizar áreas como la genómica funcional, genómica estructural y la proteómica (propio de las proteínas) y tiene gran protagonismo en la farmacéutica.

Las grandes empresas promotoras de la industria biotecnológica que denominamos laboratorios medicinales vienen desarrollando investigaciones con el objeto de producir fármacos biotecnológicos (los cuales emulan a factores biológicos naturales con la finalidad de potenciar o inhibir un efecto biológico determinado), que representan el 20 por ciento del total de medicamentos disponibles en el mercado y el 50 por ciento de los nuevos fármacos en desarrollo. Se estima que actualmente hay en uso, aproximadamente 500 medicamentos biotecnológicos; proyectándose que para el 2025 el 75 \% de los fármacos del mercado procederán de esta nueva fuente. El número de investigaciones biomédicas tanto farmacológicas como biotecnológicas se ha multiplicado por diez en los últimos veinte años, y América Latina viene resultando el blanco especial para ellas puesto que exigen la participación de humanos tanto sanos como enfermos. El uso de poblaciones pobres y carenciadas de atención a la salud, la ignorancia acerca de lo que es una investigación biomédica sumada al prestigio de la ciencia sobre todo la proveniente del norte, la carencia de legislaciones protectoras de los sujetos de experimentación, el enmascaramiento de la violación de derechos por el paso obligado de las investigaciones por comités de ética que carecen de la idoneidad y el poder necesario para impedir el atropello hacia vulnerables, hace de América Latina un terreno fértil para esas investigaciones. ${ }^{26}$ Se solapan en muchas de estas investigaciones la recolección de muestras genéticas que son derivadas a los países centrales para utilizarlas para futuras investigaciones cuyo propósito nos

25 Todavía existen científicos, sobre todo provenientes de las denominadas ciencias duras que suponen que la agenda para llevar a cabo investigaciones es independiente de la tecnología, ignorando uno de los datos sobresalientes que es que los incentivos económicos tanto estatales como empresariales tienen en la mira el desarrollo tecnológico y sobre todo, hoy, biotecnológico y en función de ello toman decisiones, es decir invierten capital. Heler Mario, Ciencia incierta. La producción social del conocimiento, Biblos, Buenos Aires, 2005; Winner, Langdon, "Do Artifacts have Politics?" en Mackenzie, D. et al (eds), The Social Shaping of Technology, Open University Press, Philadelphia, 1985.

26 Nadie desconoce la relación que hace $M$. Foucault entre el saber, sobre todo el científico y el poder que por otra parte no es nueva sino que fue ampliamente desarrollada por Comte. Foucault la considera la mayor arma de sujeción de la vida que ejerce la biopolítica. Entre otras obras ver Foucault M., Defender la sociedad. Curso en el Collège de France (1975-1976), Fondo de cultura económica de Argentina S. A., Buenos Aires, 1990; Microfísica del poder, Ediciones de la Piqueta, Madrid, 1979. 
es desconocido en el sur. La región latinoamericana está considerada como la de mayor diversidad biológica del planeta y por el la llamada biopiratería es una práctica habitual que suele esconderse detrás de investigaciones biomédicas muchas veces consideradas inofensivas y en general inútiles. Existe además una apropiación gratuita de las plantas que han sido domesticadas y seleccionadas por los agricultores en la región donde se concentra la mayor diversidad vegetal del planeta. Estos derechos autoritariamente asumidos por las transnacionales no son ni justos ni éticos, pues no reconocen todo el largo proceso de domesticación, selección y mejoramiento de plantas realizado a través de miles de años por los campesinos ya que se apropian de ello de manera gratuita o casi.

Pero sobre todo hemos de aceptar que en América Latina "La difusión de la moderna biotecnología ha tenido (sobretodo) un papel clave como vector de transformación de los sistemas agroalimentarios". ${ }^{27}$ Por ello vamos a detenernos en la biotecnología que denominamos los transgénicos y que consiste en introducir un gen en una planta o animal para cambiarle la información. Si bien es cierto que la naturaleza durante millones de años transformó los genes, el problema es que, para realizar los cambios deseados, la ingeniería genética introduce hoy artificialmente genes de diferente especie a la receptora lo cual genera dudas acerca de su inocuidad a nivel biológico, pero además produce consecuencias dañinas de tipo no biológico, no es correcto comparar el proceso de la ingeniería genética con el natural ya que se da claramente un un salto tecnológico con respecto a los procesos evolutivos, esto no se da en la naturaleza o se da en forma muy escasa o atípica. Es por ello que la intervención de la biología molecular debería terminar una vez que se logra en laboratorio la transformación del gen, incluso podría admitirse que llegara a la transformación de la planta, pero en ese momento debería dar paso a otras disciplinas científicas que pudieran evaluar, con total independencia de criterio, los posibles riesgos que representa esta transformación. Como ello es muy costoso no se hace, de modo que no se estudia el impacto directo de los OGM sobre el ambiente, y menos aún los indirectos o los efectos complejos y en cascada que estos organismos podrían ejercer, en el mediano y largo plazo, sobre el ecosistema agrícola y los ecosistemas vecinos. Hoy ya no se menciona el hambre como motivación para multiplicar los transgénicos, no sólo porque los mismos productores lo han explicitado sino porque la FAO ha confirmado que existen alimentos suficientes como para alimentar a toda la población del planeta y que el problema es la inaccesibilidad fundamentalmente porque los alimentos son mercancía en un mercado y el uso de tierras fértiles para otros objetivos disminuye la oferta, lo cual, por la ley del mercado, los encarece. En América Latina se ha cambiado el argumento del hambre por el de seguridad alimentaria. Pero basta tomar en cuenta las consecuencias de la modificación biotecnológica de la producción agraria que da origen a la denominada agricultura industrial para comprender que el argumento es mentiroso, porque ese cambio en el sistema productivo genera más daños y riesgos que beneficios y seguridades.

27 Gutman, Graciela y Lavarello, Pablo, "Economía teoría y práctica”, Nueva época, (27): I 0, 2007. 


\section{Transgénicos en América Latina}

Un recorrido sobre la producción de transgénicos en nuestra región, permitirá confirmar la sospecha de riesgo y sobre todo cómo se manifiesta una de las formas más visibles del ejercicio de un poder dominante, como es el económico, sobre las sociedades y políticas latinoamericanas.

En poco menos de 10 años, la superficie mundial sembrada con variedades transgénicas, principalmente soja, maíz, algodón y colza, llegó a I 81,5 millones de hectáreas en 20 I 4, ${ }^{28}$ concentradas en su mayor parte en Argentina, Canadá y los Estados Unidos. Esto ha sucedido haciendo oídos sordos a las advertencias de que esos productos pueden entrañar graves peligros para la salud humana, animal y el medio ambiente, ${ }^{29}$ y más aún a los daños colaterales que implica esta producción para la región. Una de ellas para nada despreciable es que en América Latina estas nuevas tecnologías están mayoritariamente en manos de unos pocos consorcios transnacionales, que ejercen un control casi total sobre la producción agrícola y a través de él sobre las economías de países que dependen de ellas por ser productores tradicionales de commodities. ${ }^{30} \mathrm{El}$ aprovisionamiento mundial de soja transgénica RR y RG, resistente al glifosato y al glucosinato de amonio, ${ }^{31}$ se concentra en cinco países del continente americano, cuatro de los cuales corresponden al Cono Sur (Brasil, Argentina, Paraguay y Bolivia, en orden de importancia). El quinto país es Estados Unidos. Brasil produce el 30\% de la soja en el mundo, solo por debajo de EE UU. Lo sigue Argentina, que aporta el 17\%. Paraguay, sexto productor mundial, cosecha el 3\%; Uruguay, el octavo, el I,2\% y Bolivia, el décimo, el 0,8\%. Este dato puede dar la perspectiva de la importancia de ocuparse de los cultivos transgénicos en América Latina ya que no sólo se cultiva soja GM sino maíz y algodón en la misma condición. Los cultivos transgénicos cubren un área de un poco más de 48 millones de hectáreas, donde la soja transgénica con resistencia a los herbicidas mencionados sigue siendo el cultivo dominante. El territorio que ocupa la soja en nuestra región ha sido denominado por la empresa Syngenta la "República Unida de la Soja": un área ocupada por unas 12 millones de personas.

Es posible considerar lo que sucede en Argentina como un ejemplo para comprender lo que afecta a los demás países de América Latina. Argentina es el segundo productor mundial de soja transgénica e importante productor de maíz y algodón GM.32 Los transgénicos que produce son el

28 Zamora, Alfredo, "La siembra de semillas modificadas genéticamente acumula 19 años de adopción continuada a nivel mundial", Fundación Antama, 28- I-20 I 5, disponible en http://fundacion-antama.org/informe-isaaa-cifras-mundiales-cultivos-transgenicos-2014/

29 En razón de ello en Asia y la Unión Europea se han impuesto severas limitaciones a su cultivo y consumo, considerando sólo el aspecto alimenticio humano, olvidando otras aplicaciones de los productos agrícolas.

30 Bárcena, A., Katz, J., Morales, C., Schaper, M., (comp.) Los transgénicos en América Latina y el Caribe. Un debate abierto. CEPAL,Santiago de Chile, 2004

31 En la próxima campaña de siembra se pretende comenzar a incorporar en algunos países como Argentina, una nueva semilla transgénica de soja, llamada Intacta RR2 PRO. Esta es una soja con genes apilados2, que es resistente a un glifosato reforzado -el Roundup Ultramax- y es a la vez Bt, que fue desarrollada por Monsanto para ser comercializada exclusivamente en Sudamérica.

32 La soja transgénica fue aprobada en Argentina en 1996. El trámite duró apenas 8 I días. De los 136 folios del expediente, 108 estaban en inglés, sin traducción, tal y como habían sido escritos por los publicistas de Monsanto. Desde entonces, la Comisión Nacional de Biotecnología (CONABIA) ha aprobado 3I "eventos transgénicos" de soya, maíz y algodón. Entre ellos, en 2012 fue el turno de la semilla de soja "RR2 Intacta". El Estado dio luz verde a este producto de Monsanto sin realizar estudios propios. 
maíz, la soja y el algodón. Los tres son resistentes a los herbicidas glifosato y glucosinato y producen toxinas insecticidas, como el gen del Bacilus thuringiensis.

En los últimos 22 años, la superficie cultivada con transgénicos en Argentina, aumentó un 50\%. Según el Ministerio de Agricultura informa que de las 34 millones de hectáreas cultivables en el país, 24 millones son destinados a los transgénicos, de estas el 59\% corresponde a la soja genéticamente modificada. ${ }^{33}$ La cosecha de soja GM del último ciclo tuvo una producción histórica de 6I,4 millones de toneladas, lo que significó un incremento de $15 \%$ respecto a la cosecha del último ciclo, que también fue récord. ${ }^{34}$ En la temporada 20 I2-20 I 3 este mismo cultivo había alcanzado 53 millones de toneladas, de estas, sólo 10 millones se exportaron como poroto, sin ningún tipo de proceso, y de los 42 millones de toneladas destinadas al procesamiento se obtuvieron 33 millones de toneladas de harina y 7,5 millones de toneladas de aceite. La resultante económica de este proceso reproduce el mismo índice de desigualdad existente en todo el planeta: los productores de soja son alrededor de 84.000: de estos el $20 \%$ es responsable del $80 \%$ de la producción y el $80 \%$ restante de los productores sólo produce el $20 \%$ del total con sus correspondientes beneficios financieros. ${ }^{35}$ Los grandes productores son empresas multinacionales, una de ellas la misma Monsanto, cuyas utilidades no quedan en el país sino que vuelan hacia el norte. El mismo esquema se reproduce en toda América Latina en que los pequeños productores han sido expulsados de sus propias tierras. El modelo agrícola que se aplica en Argentina basado en el uso de semillas transgénicas y peligrosos agroquímicos, que beneficia de manera extraordinaria a las multinacionales, los productores y el fisco, sólo puede mantenerse si se siembran grandes extensiones de tierra, es decir si está en manos de grandes empresas. ${ }^{36}$ Está claro que los beneficios comerciales generan un alto grado de desigualdad y por consiguiente mantienen relaciones de dominio tradicionales en nuestra región.

Este dominio se ve acrecentado por el carácter privado de las nuevas tecnologías y la extensión a todo el mundo del régimen de derechos de propiedad, imperante en los países desarrollados, en especial en los Estados Unidos, ya que los mismos atentan contra la autonomía de los agricultores de menores recursos. En el caso de Argentina las semilleras producen y venden las simientes trans-

Los expedientes de aprobación son confidenciales. La aprobación de los transgénicos en Argentina se hace con trámites más fáciles y económicos para las empresas. En comparación con México, por ejemplo, mientras la aprobación de un experimento en Argentina requiere 35 requisitos, en México debe cumplir con 85. Lo que en Argentina cuesta un experimento de 800 metros cuadrados: 25.000 U\$S, en México cuesta 80 mil dólares. Éxcelsior, "México en el sexto lugar en la producción de transgénicos en América Latina, Reportaje a Luis Herrera Estrella, director general del Laboratorio Nacional de Genómica para la Biodiversidad", en Zócalo Saltillo, del 7 de octubre de 20 I5. Disponible en http://www.zocalo.com.mx/seccion/articulo/mexico-sexto-lugar-enproduccion-de-transgenicos-en-al-|378308|82

33 ArgenBio (Consejo Argentino para la Información y el Desarrollo de la Biotecnología), Cultivos aprobados y adopción, 20।4, disponible en http://www.argenbio.org/index.php?action=cultivos\&opt=5

34 Ibid.

35 "Soja y el poder económico", Telam especiales, Soja y poder económico, 2013, disponible en http://www.telam.com.ar/informesespeciales/I-soja-y-poder-economico/2-el-negocio 2014.

36 Esto no sucede solo en Argentina, sino que esta modalidad de cultivo es condición necesaria para obtener ganancias dado el alto costo de los insumos (semillas y agrotóxicos) Ver Nuffield Concil on Bioethics, Genetically modified crops: the ethical and social issues, Londres, 1999 y The use of genetically modified crops in developing countries, Londres, 2004. 
formadas genéticamente, al mismo tiempo que las siembran en campos propios y arrendados, así como los agrotóxicos que esas semillas necesitan. ${ }^{37}$ Esas semilleras realizaron lobby en el Congreso de la Nación, durante 2014 y 2015 para cambiar, sin conseguirlo, el régimen legal sobre semillas que otorga el poder de regular el derecho del agricultor sobre su propia semilla bajo el concepto de "regalías extendidas". Está claro que su propósito no sólo desestimaba el perjuicio que esto representaría para los pequeños productores sino desconocía que este modo de regulación entra en conflicto con la normativa internacional contemporánea de protección al productor agrícola. Por esa ley los agricultores pueden reservar, utilizar y reutilizar semillas sin limitaciones aunque no pueden intercambiarlas con otros productores. ${ }^{38}$

El daño que produce la producción de soja GM tiene diferentes dimensiones: ambientales, sociales, económicas, políticas, médicas que no tienen que ver necesariamente con el consumo del transgénico como alimento. El daño que esto último puede producir es de muy difícil comprobación con la metodología de investigación biomédica actual, sobre todo porque implica ensayos con personas ${ }^{39}$ pero sí son altamente comprobables los daños que provocan los agrotóxicos que hoy usan tanto la soja como el maíz o el algodón que se producen en América Latina. La segunda promesa realizada por los promotores de los transgénicos a principios de los años 90 (la primera era paliar el hambre en el mundo) que fue disminuir el uso de herbicidas e insecticidas, tampoco fue cumplida. ${ }^{40}$ Para que la producción transgénica sea rentable necesita provenir de la siembra de por lo menos 500 hectáreas de campo, ${ }^{41}$-no puede hablarse de rentabilidad para pequeños productores-, y usando el método de siembra directa que puede hacerse con maquinarias y sin hombres y necesita cócteles de herbicidas e insecticidas. La desventaja de esto es que con los métodos tradicionales se utilizaban herbicidas sólo en una época del año, durante el barbecho o el descanso de la tierra, mientras que hoy se aplican casi en forma continua, porque la siembra directa permite usar los campos sin descanso. Esto ocasiona una serie de efectos adversos: uno de ellos, muy importante, es que la resistencia que manifiesta la soja frente a los herbicidas como el glifosato, el glucosinato y más actualmente el 2-4-D, que matan las malezas que invaden los sembrados, facilita la polinización cruzada, por lo que puede dispersar

37 El dato ineludible es que en América Latina, las principales productoras de transgénicos son Monsanto, (80\%) Dupont (20\%), Aventis, Syngenta y BASF el 30\%. Estas empresas producen demás el 60\% de los plaguicidas y controlan la comercialización del 23\% de las semillas comerciales transgénicas y no transgénicas.

38 La ley establece también condiciones para utilizar los derechos del agricultor: 1) que la persona sea un agricultor; 2) que haya comprado la semilla original legalmente; y 3) que haya obtenido la semilla actual de aquella legalmente comprada. Ver Artículo I5del Convenio de la UPOV, |99|, disponible en: http//www.upov.int/upovlex/es/conventions//99|/act | 99|.html

39 Uno de los estudios más recientes probando el daño de la soja transgénica es el aportado por Shiva Ayyadurai donde aparece que la soja transgénica acumula formaldehído, sustancia cancerígena, junto a una disminución drástica de glutatión, antioxidante esencial para la desintoxicación celular. El estudio analizó 6 mil 497 experimentos de 184 instituciones científicas en 23 países y pone de manifiesto la invalidez del principio de equivalencia sustancial. Shiva Ayyadurai, Prabhakar Deonikar "Do GMOs Accumulate Formaldehyde and Disrupt Molecular Systems Equilibria? Systems Biology May Provide Answers", Agricultural Sciences, Vol.6 No.7, July 10, 20 I5. Disponible en http://www.scirp.org/journal/as/

40 El consumo de pesticidas aumentó el 858 por ciento en los últimos veinte años. Aranda, Darío, "Semillas para el debate", Página 12, 19-2-20 I, disponible en http://www.paginal 2.com.ar/diario/sociedad/3-240 I 20-20 I 4-02- I9.html.

4I En Argentina de productores agrícolas hay casi 17 mil productores que tienen entre 61 y 150 hectáreas, y 4.170 con 45 I a 600 hectáreas. Más del $60 \%$ de la agricultura se hace sobre tierras de terceros. 
esa característica de resistencia a los herbicidas, a plantas que no han sido modificadas genéticamente y convertirlas en OGM. Esto ha ocurrido y sigue ocurriendo y esa multiplicación de resistencia a las malezas produce un efecto contraproducente cuando da lugar al desarrollo de malezas más agresivas o de parientes silvestres con mayor resistencia a las enfermedades o a los estreses abióticos, trastornando el equilibrio de los ecosistemas: dañando la flora y la fauna. Ese desequilibrio se vuelve cada vez peor ya que ante las supermalezas los productores se ven obligados a aumentar las dosis de agrotóxicos, lo cual contamina las aguas, al filtrarse hacia las napas subterráneas. ${ }^{42}$ Actualmente se aplican 12 litros de glifosato en la misma hectárea y por año, en muchos casos "potenciados" con otros herbicidas como graminicidas u hormonales, contra los 3 litros/ha utilizados en los años 96/97. En Argentina, el uso de glifosato pasó de I millón de litros (antes del año 96) a 200 millones de litros por año. ${ }^{43}$ En 20 I5, la Comisión Nacional Asesora de Biotecnología Agropecuaria (CONABIA) aprobó la "soja DAS-44406-6" de la empresa Dow AgroSciences, resistente a los agroquímicos glifosato, glufosinato de amonio y 2-4-D. ${ }^{44}$ El dictamen señala que no representa riesgos para la salud ni para el ambiente. Sin embargo, más allá de lo que una comisión conformada de manera poco ética, pueda afirmar, el aspergeo con estos herbicidas no sólo imposibilita la coexistencia con otro tipo de agriculturas, pues acabarían con cualquier otro cultivo que no sea resistente al herbicida, sino que, como marcamos intensificará el surgimiento de supermalezas. El resultado es no sólo el aumento del uso de esas sustancias potenciadas por otras sino la exigencia de los productores, a los laboratorios, de contar con químicos cada vez más potentes.

Todo esto se desarrolla al margen del fenómeno de la deriva por el cual estos venenos no sólo afectan a otras producciones sino también y de manera grave a las poblaciones que viven en la zona de influencia de los cultivos. Recordemos que en marzo de 2015 la OMS declaró que el glifosato puede causar cáncer "Hay pruebas convincentes de que el glifosato puede causar cáncer en animales de laboratorio y hay pruebas limitadas de carcinogenicidad en humanos (linfoma no Hodgkin)". Con esta declaración, la OMS le dió la razón a Seralini, Reylea y Bellé y en Argentina a Carrasco, investigadores que mostraron la toxicidad de este producto en humanos. ${ }^{45}$ Esto que es sumamente

42 Los productos que se aplican junto con él para mejorar su absorción, como los coadyuvantes o surfactantes, en ciertas condiciones pueden resultar más tóxicos para el medio silvestre que el herbicida mismo.

43 La gaceta, El productor de grano debe prepararse para enfrentar una campaña "tecnológica", I 8- I 0-20 I 5, disponible en http://www. lagaceta.com.ar/nota/6 I 7842/economia/productor-grano-debe-prepararse-para-enfrentar-campana-tecnologica.html

44 Aranda, Darío, Op. Cit. La Secretaría de Agricultura, Ganadería y Pesca de la Nación autorizó la comercialización condicionada, en todo el territorio argentino, de la soja tolerante a glifosato, glufosinato de amonio y 2,4-D (diclorofenoxiacético) desarrollada por Dow AgroSciences (evento DAS-44406-6). Esta autorización es condicionada a obtener el permiso de importación en la República Popular China. Es decir que el importado acepte un poroto de soja producido por una planta resistente al 2,4D. El 2-4-D es un herbicida que se utiliza desde 1940, muy cuestionado a nivel internacional, que fue prohibido en Dinamarca, Noruega y Suecia. Es tristemente célebre por formar parte junto al glifosato del agente naranja usado en Vietnam.

45 Seraline et al, "Long term toxicity of a Roundup herbicide and a Roundup-tolerant genetically modified maize," Food and Chemical Toxicology (50) November 20 I2; Relyea, R. A.. "The lethal impacts of Roundup and predatory stress on six species of North American tadpoles." Arch. Environ. Contam. Toxicol. 48: 35I-357, 2005;. Marcl', Mulner-Lorillon O , Bellé R., "Glyphosate-based pesticides affect cell cycle regulation", Biol Cell. Apr; 96(3):245-9, 2004.; Paganelli A', Gnazzo V. Acosta H, López SL, Carrasco AE, "Glyphosate-based herbicides produce teratogenic effects on vertebrates by impairing retinoic acid signaling", Chem Res Toxicol. Oct 18;23(I0): I 586-95, 20 I0; Pryme, lan F. and Lembcke, Rolf, "In Vivo Studies on Possible Health Consequences of 
preocupante, no puede ser probado definitivamente por la falta de apoyo económico a las investigaciones que reafirman datos recabados por las poblaciones ya que la agenda de las investigaciones reconocidas como científicas, es totalmente dependiente de los intereses de los capitales privados. Un informe publicado en la revista Nutritional Health, I. F. Pryme y R. Lembcke resalta que los estudios científicos sobre transgénicos no financiados por la industria han encontrado problemas con serias implicancias para la salud humana, mientras que aquellos estudios financiados por la industria de alimentos nunca encuentran ningún problema. LaFDA, al aprobar los alimentos producidos con transgénicos, "depende casi totalmente de la notificación voluntaria de las compañías de biotecnología”, advierten los científicos húngaros Arpad Pusztai y Susan Bardocz. ${ }^{46}$

Esto permite poner de relieve que el problema no es sólo ambiental sino que termina siendo médico-ambiental. La disminución de la resistencia de las malezas a los agrotóxicos a que son inmunes los OGM, obliga, a los productores a aumentar la dosis de los mismos, esto no sólo son probadamente dañinos para las especies animales, algunas de las cuales como las abejas desaparecen definitivamente, sino que dañan también a los humanos aumentando la prevalencia de cánceres, deformidades, esterilidad y alergias en los que de alguna manera son afectados por ellos. Se suma a esto que provocan emisión de gases de efecto invernadero como el N20 (óxido nitroso), con todo lo que esto significa tanto para el ambiente como para el ser humano.

Pero el daño no se reduce a lo médico-ambiental sino que afecta otros ámbitos de la vida: el social por ejemplo, generando desocupación. El cultivo de los transgénicos y especialmente de la soja, resulta altamente mecanizado, por lo que desplaza la mano de obra, puede hacerse prácticamente sin hombres ya que, para ser rentable, exige ser cultivado en alta escala. Esto genera el éxodo de trabajadores del campo y pequeños productores, volviendo a instaurar los latifundios, esta vez en manos de grandes capitales internacionales. ${ }^{47}$ Los productores son bancos, laboratorios, empresas de seguro que no conocen la tierra de dónde salen sus productos y no les interesa el futuro de la misma ni el de sus pobladores tradicionales. Además, al momento que ésta pierda capacidad productiva, la abandonarán buscando negocios en otro lado. Este parece un daño menor, sin embargo genera una relación con la tierra de total desinterés por ella, la tierra pasa a ser concebida como fuente de producción, y sus frutos productos a comercializar. Los pequeños campesinos, los nativos que tenían una relación de pertenencia a la tierra, y los no nativos, los inmigrantes que se habían aferrado a ella como si fuera propia, han sido expulsados y obligados a vivir en grandes centros urbanos donde pueden ser dominados más fácilmente por el desarraigo al que se ven sometidos. La ocupación de zonas despreciadas en las ciudades por su carencia de servicios, su dificultad de acceso, su carácter

Genetically Modified Food and Feed — with Particular Regard to Ingredients Consisting of Genetically Modified Plant", Materials Nutrition and Health, vol. 17, I: I-8, January 2003,

46 Citado por Ewen, Stanley y Pusztai, Arpad en "Riesgos en la salud por alimentos genéticamente modificados", The Lancet, Volumen 354, Edición 9179, 21 Agosto 1999.

47 Por cada 1.000 hectáreas de soja, trabajan solamente 15 personas, en alto grado en negro, mientras que I.000 hectáreas de caña de azúcar emplean 350 personas y 1.000 de cítricos emplean 1.300 personas. Soja y poder económico, Telam especiales, Op. Cit. 
de inundables, por grandes grupos de desplazados de su tierra, ha generado alrededor de todas las grandes ciudades latinoamericanas la presencia de los denominados migrantes porque carecen de lugar de pertenencia al haber sido arrojados de sus tierras, lo cual aumenta la desigualdad y sobre todo impide definitivamente la solidaridad.

Tanto la tierra como sus productos sólo tienen un solo interés para los que desarrollan la agricultura comercial o industrial: el de algo que puede ser vendido para generar dinero. Son mercancías que sólo tienen valor en el mercado, de modo que carecen de cualquier otro tipo de valor y no merecen respeto. La máscara que se había inventado para justificar los transgénicos, que era la alimentación de la humanidad vimos que cayó hace tiempo y que sólo permanece como justificación la obtención de ganancias monetarias, sean estas individuales o estatales. Esto lo patentiza el hecho de que la mayor ganancia proviene de vender la soja elaborada como combustible, como etanol (también el maíz y el algodón). Muchos ambientalistas rechazan el concepto de agrocombustibles porque consideran que el uso de los frutos de la tierra debe ser primordialmente para la alimentación humana. En este caso el uso es para alimentar el motor de los automotores.

Sin embargo, aquellos que buscan justificar lo injustificable, promocionan la producción de etanol como benéfico para el ambiente, puesto que produce menos carbono. Este argumento muestra la manipulación a que son sometidos los individuos y los pueblos utilizando los tres instrumentos mencionados más arriba: la ciencia, la biotecnología y la palabra. Al recurrir a razones ambientales, a partir de una preocupación por el planeta y el futuro que viene adquiriendo estado público, lo que se busca es ocultar, tras estos discursos, que la producción de etanol, genera un grave daño a la economía alimentaria del planeta: el sobrecultivo de la tierra, práctica necesaria para que los GM produzcan ganancias comerciales, acelera su deterioro; el uso masivo de agua para mantener estos cultivos que sólo alimentarán motores, impide que pueda usarse para producir los alimentos sanos que necesita el planeta. Mientras se usa la tierra para producir complementos para los hidrocarburos cuya combustión daña la atmósfera, se invierten enormes cantidades de dinero en tratar de producir alimentos sin tierra y en generar tecnologías que permitan bajar la contaminación del aire, la tierra y el agua y aminorar los efectos del cambio climático uno de cuyos factores claves es esa combustión.

Las mismas condiciones se reproducen en todos los países latinoamericanos que han adoptado el cultivo de soja GM como panacea económica.

Bolivia: se aprobó el cultivo de soja transgénica en 2005. Está prohibida la producción del otros transgénicos, sin embargo desde 2012 se experimenta con maíz, algodón y papa sin autorización del gobierno y no sólo ello sino que ensayos realizados el 2010 en la región del Chaco -Santa Cruz, Chuquisaca y Tarija- evidenciaron que cuatro de 187 muestras de maíz eran transgénicas. Sin embargo esto no generó el seguimiento de los casos ni la adopción de acciones de control más estricto, pese a tratarse de especies de las que Bolivia es centro de diversidad genética. En 2015 de más de un millón de hectáreas cultivadas con soja transgénica en Santa Cruz, el 98 por ciento es transgénico. Aunque se mantiene la prohibición para otros transgénicos -el argumento es la soberanía alimentaria-, no 
está asegurado ni garantizado que los ecosistemas y el medioambiente estén libres de alteraciones y contaminación.

Ecuador: La Constitución de la República del Ecuador, menciona en su artículo 401 menciona: "Se declara al Ecuador libre de cultivos y semillas transgénicas". Existen sin embargo proyectos alentados por la presidencia de transformar algunos cultivos de soja en transgénicos. En la actualidad Ecuador importa soja de Argentina entre otros países y esa soja es transgénica. ${ }^{48}$

Paraguay: el territorio ocupado por la soja transgénica es el 8\% de todo el territorio paraguayo: 3 millones de hectáreas, constituyéndose con ello en el cuarto exportador de soja del mundo. Este país quintuplicó entre 2009 y 2013 la cantidad de agroquímicos importados para los cultivos

México: hasta el 2006 se habían emitido autorizaciones a experimentar con 31 transgénicos de soja, papa, canola, jitomate, algodón y alfalfa. Sólo se explotan actualmente de forma comercial la soja y el algodón RR, mientras que el maíz sigue en nivel experimental y piloto. Actualmente, México ocupa el lugar 16 del ranking mundial, con 200,000 hectáreas dedicadas a la producción GM de soja y algodón. Desde 2013 y gracias a una demanda colectiva, estaban detenidos los permisos para que empresas como Monsanto sembraran maíz transgénico, en razón del riesgo de perder la gran variedad de maíces que posee México. Este 19 de agosto de 2015, el juez duodécimo de distrito de materia civil del primer circuito, Francisco Peñaloza Heras, resolvió suspender esta prohibición desoyendo el argumento de que poner en manos de transnacionales el alimento más importante del país, no sólo provocará una mayor dependencia alimentaria y económica sino que más de 60 maíces nativos se contaminarán y seguramente muchos desaparecerán. ${ }^{49}$ Durante el 2014 se sembraron II 8.899 hectáreas de cultivos, 16.879 más que en 2013. En 2012, se otorgó el primer permiso para siembra de soja y el resultado fue que en Campeche se deforestaron 38 mil hectáreas de selva virgen y en Hopelchén, lugar dedicado a la apicultura los productores sufrieron una altísima merma de la producción de miel. Recientemente se aprobó la siembra de 253 mil hectáreas de soja transgénica en la Península de Yucatán, pero no ha comenzado a sembrarse por la resistencia de las poblaciones. El principal cultivo con semilla modificada es el maíz, con un crecimiento sostenido, seguido del algodón.

Chile: sólo se plantan transgénicos para comerciar la semilla, para el uso alimentario se importan de Argentina. La evolución de la superficie sembrada con semillas transgénicas ha crecido considerablemente desde el año 1992 y para la última temporada sobrepasó las 35.500 hectáreas. En la temporada 2012/2013 de la superficie total de semilleros transgénicos en el país (35.507 hectáreas), el $82 \%$ correspondió a semilleros de maíz (29.244 ha), el I 2\% a semilleros de canola (4.35I ha) y el $6 \%$ a semilleros de soja (1.907 ha). ${ }^{50}$

48 Intriago Barreno, Richard, "La situación de los transgénicos en Ecuador en 20 I5", FECAOL - ACCIÓN ECOLÓGICA, en Ballenitasi, 2015, disponible en http://www.ballenitasi.org/20 I5/07/la-situacion-de-los-transgenicos-en.html

49 Ribeiro, Silvia, Ibid.

50 Chile bio, Situación en Chile, I I-10-20 I5, disponible en http://www.chilebio.cl/pt_situacion_chile.php 
Venezuela: es el único país de la región donde está prohibido el uso de cualquier semilla transformada genéticamente por una ley ratificada por plebiscito en 2013.

Brasil: ha producido en el año 20।4-20I5 42 millones de toneladas. En el ranking de países productores de cultivos biotecnológicos, ocupa el segundo lugar con una superficie de 42 '2 millones de hectáreas, casi dos millones más que en el año 2013, destacando especialmente el incremento de la producción de una nueva variedad de soja transgénica. ${ }^{51}$ Su cultivo fue autorizado en 1998 por la Comisión Técnica Nacional de Bioseguridad, CTNBio, pero había sido sembrada ilegalmente durante años. Ya en el año 2012 representaba el 85\% de toda la soya plantadas en el país, para un total de más de 21 millones de hectáreas. Se atribuye el aumento de productividad al uso de semillas GM, sin embargo, el ingeniero agrónomo e investigador de la estatal Universidad de Campinas (Unicamp) Mohamed Habib cuestiona que el uso de transgénicos aumente la productividad. Habib, junto a otros 815 científicos agrónomos de 80 países, firmó un manifiesto que pide el fin de los transgénicos.

Respecto del maíz, se ha adoptado el maíz transgénico BT en Argentina, Brasil, Uruguay, Paraguay, Chile (sólo para la producción de semillas), Colombia, Panamá y Honduras. Se han aprobado eventos de maíz transgénico Bt, con resistencia a herbicidas y con genes apilados de ambos tipos de caracteres en Costa Rica y Chile (para la producción de semillas), México (para evaluaciones de campo), Brasil, Argentina, Panamá, Honduras, Uruguay y Paraguay. En Colombia se siembran además flores azules de exportación: rosas y claveles.

No toda población se entrega gustosa a este juego con genes, bacterias, virus que implica la experimentación con transgénicos. Además de la resistencia de las localidades que las ven avanzar sobre sus cultivos tradicionales o el ambiente donde viven desde hace siglos, existen organizaciones que llevan adelante investigaciones y recaban datos sobre los daños que este tipo de producción agrícola genera en todo el continente. Entre ellas la Red por una América Latina Libre de Transgénicos, creada en 1999, que está conformada por organizaciones ecologistas, de derechos humanos, de agricultores y campesinos, trabajadores de la salud y académicos de América Latina, preocupados por la expansión de los cultivos transgénicos en la región.

Dos aspectos de esta realidad no podemos ignorar: uno que los agrotóxicos que se usan para ciertos cultivos a los que los mismos son inmunes son dañinos para la vida humana y la no humana. Esto está probado por multitud de ejemplos y estudios en toda América Latina. Lo segundo es que la producción de transgénicos no tiene justificativo económico aunque si tenga una razón financiera. La economía no sólo debe tomar en cuenta las ganancias monetarias

Por último, pero no por ello menos grave es el hecho de que las instituciones de investigación de los países en desarrollo estén largamente a la zaga con respecto a las grandes transnacionales en todo lo referente a ingeniería genética. Fácil es advertir que se trata de una esfera del conocimiento de especial importancia para América Latina y el Caribe, dado el atraso en que se encuentran sus institutos de investigación, y dada su riqueza en recursos naturales y diversidad genética.

5 I Gastronomía y Cia. Informe sobre el crecimiento de los transgénicos en el mundo, disponible en www.gastronomiaycia.com/20 I 5/.../ informe-sobre-el-crecimiento-de-los... 
El festival de bacterias que representa toda la experimentación biotecnológica, no puede dejarnos tranquilos. ${ }^{52}$ la misma ciencia biológica reconoce su ignorancia respecto de la reacción de los organismos ante la invasión bacteriana que puede resultar una comida elaborada con transgénicos. Existen riesgos de transferir toxinas de una forma de vida a otra, de crear nuevas toxinas o de transferir compuestos alergénicos de una especie a otra, lo que podría dar lugar a reacciones alérgicas imprevistas. Si bien es cierto que la biotecnología se ha convertido en uno de los negocios más importantes de la actualidad, ya que es una fuente económica de valor creciente, ${ }^{53}$ ello no es excusa para no ser sometida a juicios de valor éticos y políticos, sobre todo cuando además de los daños ambientales, sociales, médicos, culturales encontramos que permiten situaciones históricas, como el monocultivo, que han permitido que América Latina fuese dominada por poderes políticos extraños a sus intereses. "Los gobiernos de la región han sido fieles impulsores de la agroindustria, promoviéndola como un camino para alcanzar la reprimarización de las economías en América Latina con grandes impactos en los territorios, proceso llamado neodesarrollismo". ${ }^{54}$

América latina pasa a constituir así un continente liberado para la experimentación desarrollo. Como resultado, en los últimos años hemos vivido un proceso de experimentación biotecnológica. La fascinación por la ciencia, la corrupción económica, el anhelo de desarrollo y bienestar social a la manera de los países del "primer mundo" impide por un lado legislaciones que pongan límites a la extracción de material genético por un lado y a la experimentación con su gente, por otro. Tampoco se realizan investigaciones locales para garantizar que los productos que provienen de la biotecnología no sean dañinos para la salud a nivel biológico. Las instituciones de investigación de los países en desarrollo están largamente a la zaga con respecto a las grandes transnacionales en todo lo referente a ingeniería genética puesto que la investigación, sobre todo en ciencias duras como es la biología y la genética, sufren un alto grado de colonización, repitiendo lo que se hace en los países desarrollados que sólo responde a los intereses de las empresas. Son precisamente la biología y la genética las que tendrían que encontrar procedimientos y técnicas para investigar el posible daño de las modificaciones transgénicas, donde se mezclan especies vegetales con especies animales, por ejemplo, sobre el organismo humano. Se ha escrito mucho sobre el daño político, económico, social, antropológico incluso cultural del desarrollo de estas investigaciones, pero los datos provenientes

52 Los agentes biológicos se clasifican, en función del riesgo de infección, en cuatro grupos: https://es.wikipedia.org/wiki/ Biotecnolog\%C3\%ADaAgente biológico del grupo I: aquel que resulta poco probable que cause una enfermedad en el hombre. Agente biológico del grupo 2: aquel que puede causar una enfermedad en el hombre y puede suponer un peligro para los trabajadores, siendo poco probable que se propague a la colectividad y existiendo generalmente profilaxis o tratamiento eficaz. Agente biológico del grupo 3: aquel con muchas probabilidades de que se propague a la colectividad y sin que exista generalmente una profilaxis o un tratamiento eficazAgente biológico del grupo I: aquel que resulta poco probable que cause una enfermedad en el hombre. Agente biológico del grupo 2: aquel que puede causar una enfermedad en el hombre y puede suponer un peligro para los trabajadores, siendo poco probable que se propague a la colectividad y existiendo generalmente profilaxis o tratamiento eficaz. Agente biológico del grupo 3: aquel con muchas probabilidades de que se propague a la colectividad y sin que exista generalmente una profilaxis o un tratamiento eficaz.

53 Rifkin, Jeremy, La era del acceso. La revolución de la nueva economía, Paidos Ibérica, México, 2000.

54 Manzur, María Isabel, Cárcamo, María Isabel, América Latina: La transgénesis de un continente.Visión crítica de una expansión descontrolada, II ed., Ediciones Böll, México, 2014. 
de la ciencia biológica sólo han sido desarrollados, e incluso escasamente, por los laboratorios que producen y comercializan los transgénicos.

Cuando se cuestiona el uso de transgénicos para la alimentación se producen manifestaciones en el sentido de que no hay nada probado que muestre que los transgénicos son dañinos para la biología humana y animal, pero tampoco ha sido probado que no son dañinos. Frente a esta situación, lo que recomienda la prudencia y algunas legislaciones en otros ámbitos como el del daño ambiental adoptar el principio de precaución que indica que sólo puede consumirse una sustancia nueva o realizarse algún tipo de intervención sobre el ambiente cuando su beneficio no ofrezca dudas. Este principio es la razón de ser de la experimentación científica, sin embargo, la biotecnología no puede asegurar que los productos de las transgénesis no sean dañinos para la vida humana y animal.

\section{Reflexiones finales}

Estas cuestiones marcan riesgos que afrontan todos los países y pueblos en américa Latina, riesgos que, por un lado, nos son impuestos y, por otro, no podemos controlar, ${ }^{55}$ frente a los cuales crece la necesidad de evitarlos. El primer paso es dejar de creer en el mito de una tecnociencia, sobre todo una biotecnología como la que tiene la clave de una vida buena, como aquel conocimiento que librará a los pueblos del dolor y el sufrimiento. Ello evitará que sea ella misma la que ejerza el poder de regularse para asignar los límites y finalidades de su ejercicio. ${ }^{56}$

América Latina debe tener en claro su valor como una de las regiones con mayor diversidad natural y cultural, lo cual la hace un botín codiciado, sobre todo porque la biodiversidad se ha convertido en el más precioso y buscado "recurso natural" en los últimos años. Una de las cuestiones a tomar en cuenta cuidadosamente es la de la propiedad de las patentes de descubrimiento, que no ha sido zanjada y sigue constituyendo un instrumento de dominio poderoso. De hecho la percepción de actividades de conservación de dicha biodiversidad ha servido a los países centrales como medio de posicionamiento sobre los espacios de mayor densidad o especificidad germoplasmática, lo que ha llevado a renovar la dimensión territorial de la disputa por el poder entre los que manejan los mercados. ${ }^{57}$

55 En lo que Beck denomina "riesgo cerrado a la decisión" que asocia al uso de agrotóxicos, afirmando que la imposibilidad de preverlos y por consiguiente evitarlos proviene de la "ingenuidad industrial de la población rural que tiene que ver con que no leen ni escriben", Beck, Ulrich, La sociedad del riesgo. Hacia una nueva modernidad, Paidos, Bs. As., I998: 47.

56 Dos ejemplos: en Argentina se vienen utilizando desde hace más de 15 años diferentes técnicas de fecundación asistida. No sólo la sociedad no ha participado de un debate acerca del posible beneficio de estas técnicas, ni conoce los modos en que se realizan, sus resultados, sus alternativas, sino que la única regulación a su práctica proviene de un código de ética establecido por las Sociedades de Fecundación Asistida. La regulación y el control de los procedimientos para la obtención de OGM (organismos genéticamente modificados) aplicables a la agricultura, se regula de acuerdo a los reglamentos de la CONABIA que es la Comisión Nacional de Biotecnología Agropecuaria y que está constituída, en un tercio de sus componentes, por representantes de las empresas que realizan transgénesis de semillas.

57 Ceceña, Ana Esther, “La territorialidad de la dominación.Estados Unidos y América Latina”, en AAWV Chiappas I 2, 200 I, Instituto de Investigaciones Económicas, Universidad Nacional Autónoma de México. 
En el año 2004, la autora de este trabajo publicó un libro con los daños de los OGM, tanto biológicos como sociales políticos, alimentarios, culturales, económicos en Argentina, México, Ecuador y Brasil ${ }^{58}$ Ya entonces se conocía, por lo menos el daño que la biotecnología estaba produciendo en la esfera del agro y se lo denunciaba. El poder político de entonces y al actual siguen discutiendo lo que ha sumado evidencias dando pie sobre todo a argumentos científicos que provienen de otras latitudes. Es la bioética, con la ética y la política la encargada de imaginar un espacio multidisciplinario en que el marco de decisión esté dado por la plena vigencia del derecho a la vida y la salud. La resultante será un entre, en que estemos todos involucrados, del que no podamos quedar fuera, en que el derecho sea algo más y mejor que aquello que los sujetos reciben o pierden según el humor de las instituciones de gobierno, el entre que reclama la ética como espacio justo de la convivencia y la solidaridad ${ }^{59}$ cuya respuesta política son las declaraciones universales de derechos humanos en sus diferentes formatos. ${ }^{60}$ La vida ética de los individuos sólo alcanza su auténtica manifestación cuando se hace política decía Aristóteles, es decir cuando ese bien que cada uno busca para sí mismo se convierte en bien común. Esas declaraciones están sustentadas sobre valores éticos como la igualdad y la solidaridad que deberían alentar todas las intenciones de científicos, tecnócratas y sobre todo políticos.

No es ningún secreto que vivimos en un mundo desigual. ¿Cómo se manifiesta esa desigualdad? En que mientras algunos multiplican sin límite sus ganancias comerciales, sus ocios y placeres, sus comodidades y beneficios sociales, una gran parte de la humanidad, (hoy se considera que el 30 \%), accede con grandes dificultades a la mera supervivencia, lo cual pone en riesgo constante su vida. ${ }^{61}$ No podemos olvidar, al hacer este análisis, que América Latina es el continente más desigual de planeta, ${ }^{62}$ por consiguiente nuestra mirada sobre él es profundamente interesada.

Es casi una consecuencia lógica obligada que en sociedades desiguales no exista la solidaridad, puesto que la condición de la misma es compartir condiciones de vida que implican reconocimiento de historia y futuro común, cooperación en el mantenimiento y construcción de la vida. La desigualdad incluso se manifiesta en el uso del poder que cada vida posee como aptitud para transformar el mundo donde se desarrolla, vemos cómo algunas vidas usan ese poder para el propio beneficio y no, por consiguiente, para el beneficio común que sería el mandato de la ética. Sólo un mundo solidario entre iguales puede alcanzar la justicia que es el nombre que damos a las relaciones éticas

58 Pfeiffer, M.L., Transgénicos. Un destino tecnológico para América Latina, (editora), Ed. Suarez, Mar del Plata, 2002, págs. 225.

59 Ver Cragnolini, Mónica B., Moradas nietzscheanas. Del sí mismo, del otro y del

"entre", Buenos Aires: Ediciones La Cebra, 2006, 203 págs., Pfeiffer, ML, 2014, Op. Cit., cap: "Espacio y modernidad".

60 Me refiero fundamentalmente a la Declaración Universal de Derechos Humanos de 1948 y al Pacto Internacional de Derechos Económicos, Sociales y Culturales, 1966.

6I El informe de 2015 de la FAO considera que 800 millones de personas hoy sufren hambre. FAO Alcanzar el hambre cero: combinar la protección social con las inversiones a favor de los pobres, Comunicado conjunto de la FAO/PMA/FDA, 10 de julio 20I5. Disponible en www.fao.org/news/story/es/itam/298252/icode

62 "Según el Banco Mundial y el Centro de Estudios Distributivos, Laborales y Sociales (CEDLAS), América Latina es la segunda región más desigual del planeta (52,9 de coeficiente de Gini), apenas por debajo del África Subsahariana (56,5) Ver Caetano, Gerardo, Pobreza y desigualdad en América Latina (I980-20I4), El País, 30-3- 20I5, disponible en http://blogs.elpais.com/ contrapuntos/20 I 5/03/pobreza-y-desigualdad-en-america-latina- | 980-20 |4.html 
entre los hombres. Por consiguiente una sociedad desigual atenta desde el vamos contra la igualdad y la solidaridad y por consiguiente es injusta.

Desde América Latina, al reconocer sus tradiciones, su apego a la tierra, su relación ancestral con ella como una madre, es posible comprender que la relación tecnológica, incluso más la biotecnológica con los seres humanos y la naturaleza tienen su origen en el desarrollo capitalista del SXX y su concentración de poder para la producción y la manutención de la propiedad, tanto de la tierra como del otro (el trabajo del obrero, el uso de la familia, el maltrato y la manipulación de la mujer) y el saber, juega un rol fundamental en ello como lo marca Foucault.

El derecho debe verse como exigencia de respeto incondicionado a todo ser humano ya que su dignidad es la misma en todos pero se manifiesta especialmente en situaciones de desamparo o indefensión y no exageramos en nada al afirmar que frente a la biotecnología, todos esos procesos incomprensibles para un lego, todas esas promesas de un mundo y una vida maravillosas, todos estamos indefensos. No tenemos argumentos que esgrimir sin parecer trogloditas, porque es imposible contraponer argumentos a los sueños hechos realidad que nos propone la biotecnología, desde curar la enfermedad hasta recuperar la juventud pasando por la posibilidad infinita de comunicación y sofisticación de la vida. Debemos obligarnos a reconocer lo que es posible y debe serlo de lo que es una fantasía elaborada con la finalidad de evitar que construyamos un mundo en que impere la justicia. El sueño que debemos alentar es el de un mundo de seres humanos respetuosos del otro, en que se reconozcan los derechos de cada ser humano a ser quien es pero al mismo tiempo se deje claro que ser humano significa ser fundamentalmente ser con otros porque como seres humanos somos finitos, con grados de impotencia importantes, necesitados por consiguiente, pobres por consiguiente y que es el estar con el otro, "en la calle, codo a codo", bregando por la igualdad, instaurando la justicia, viviendo una vida compartida, es la única riqueza que colma la carencia fundamental que todos sufrimos como humanos.

\section{Bibliografía}

Aranda, Darío, "Semillas para el debate", Página I2, 19-2-20 I4, disponible en http://www.pagina I 2.com.ar/diario/ sociedad/3-240 I 20-20 I4-02-19.html

Aranguren, José Luis, El protestantismo y la moral, Ed. Sapientia, Madrid, 1954.

ArgenBio (Consejo Argentino para la Información y el Desarrollo de la Biotecnología), Cultivos aprobados y adopción, 20 I 4, disponible en http://www.argenbio.org/index.php?action=cultivos\&opt=5

Bárcena, A., Katz, J., Morales, C., Schaper, M., (comp.) Los transgénicos en América Latina y el Caribe. Un debate abierto. CEPAL, Santiago de Chile, 2004

Beck, Ulrich, La sociedad del riesgo. Hacia una nueva modernidad, Paidos, Bs. As., 1998. 
Bosch, Joan, "Combinar investigación e innovación: el reto de los institutos Fraunhofer" en AAVV, El papel de la ciencia básica para el desarrollo tecnológico: Repercusiones en los aspectos sociales y humanísticos, Alexander Von Humboldt Stifftung de España, Alcalá de Henares, 2007.

Caetano, Gerardo, "Pobreza y desigualdad en América Latina (I980-20I4)", El País, 30-3- 20I5, disponible en http://blogs.elpais.com/contrapuntos/20 15/03/pobreza-y-desigualdad-en-america-latina-1980-20 I4.html

Ceceña, Ana Esther, "La territorialidad de la dominación. Estados Unidos y América Latina”, en AAVV Chiappas 12, 200 I, Instituto de Investigaciones Económicas, Universidad Nacional Autónoma de México

Chile bio, Situación en Chile, I I- I0-20 I5, disponible en http://www.chilebio.cl/pt_situacion_chile.php

Comte, A., Cours de Philosophie Positive, 6 T., Bachelier, Paris, I830-1842

Cragnolini, Mónica B., Moradas nietzscheanas. Del sí mismo, del otro y del"entre", Buenos Aires: Ediciones La Cebra, 2006, 203 pp.,

Declaración Universal de Derechos Humanos de 1948 y al Pacto Internacional de Derechos Económicos, Sociales y Culturales, 1966.

Ewen, Stanley y Pusztai, Arpad en "Riesgos en la salud por alimentos genéticamente modificados", The Lancet, Volumen 354, Edición 9179, 21 Agosto 1999.

Éxcelsior, "México en el sexto lugar en la producción de transgénicos en América Latina, Reportaje a Luis Herrera Estrella, director general del Laboratorio Nacional de Genómica para la Biodiversidad", Zócalo Saltillo, del 7 de octubre de 2015. Disponible en http://www.zocalo.com.mx/seccion/articulo/mexico-sexto-lugar-enproduccion-de-transgenicos-en-al-1378308|82

FAO Alcanzar el hambre cero: combinar la protección social con las inversiones a favor de los pobres, Comunicado conjunto de la FAO/PMA/FDA, I0 de julio 20 I 5. Disponible en www.fao.org/news/story/es/itam/298252/icode

Foucault M., Defender la sociedad. Curso en el Collège de France (1975-1976), Fondo de cultura económica de Argentina S. A., Buenos Aires, 1990;

Microfisica del poder, Ediciones de la Piqueta, Madrid, 1979.

Gastronomía y Cia. Informe sobre el crecimiento de los cultivos transgénicos en el mundo, 20।4, disponible en www.gastronomiaycia.com/20 I5/.../informe-sobre-el-crecimiento-de-los...

Gudynas, E., Derechos de la Naturaleza. Ética biocéntrica y políticas ambientales, RedGE, PDTG, CooperAcción y CLAES, Lima, 2014.

Gutman, Graciela y Lavarello, Pablo, "Economía teoría y práctica”, Nueva época, (27):10, 2007.

Heidegger, M., Sendas Perdidas, "La época de la imagen del mundo" (capítulo), Losada, Bs. As., 1960

Heler Mario, Ciencia incierta. La producción social del conocimiento, Biblos, Buenos Aires, 2005.

Intriago Barreno, Richard, "La situación de los transgénicos en Ecuador en 2015", FECAOL - Acción Ecolótica, en Ballenitasi, 2015, disponible en http://www.ballenitasi.org/20 I5/07/la-situacion-de-los-transgenicos-en.html 
Junges, R., "Sostenibilidad: Desarrollo sustentable y equidad", Rev.Redbioética/UNESCO, Año 6, I (I I): enero-junio 2015.

La gaceta, El productor de grano debe prepararse para enfrentar una campaña "tecnológica", I 8- 10-20 I 5, disponible en http://www.lagaceta.com.ar/nota/6 17842/economia/productor-grano-debe-prepararse-para-enfrentarcampana-tecnologica.html

Ladrière, Jean, El reto de la racionalidad, UNESCO, París, 1997.

Löwith, Karl, El sentido de la historia, Aguilar, Madrid, 1968.

Manzur, María Isabel, Cárcamo, María Isabel, América Latina: La transgénesis de un continente.Visión crítica de una expansión descontrolada, II ed., Ediciones Böll, México, 2014.

Marc J., Mulner-Lorillon O., Bellé R., "Glyphosate-based pesticides affect cell cycle regulation", Biol Cell. Apr; 96(3):245-9, 2004.

Maréchal, Jean-Paul, "L'écologie de marché, un mythe dangereux", Le Monde Diplomatique, october, 1966.

Nuffield Concil on Bioethics, Genetically modified crops: the ethical and social issues, Londres, 1999 The use of genetically modified crops in developing countries, Londres, 2004

Paganelli A., Gnazzo V, Acosta H, López SL, Carrasco AE, "Glyphosate-based herbicides produce teratogenic effects on vertebrates by impairing retinoic acid signaling", Chem Res Toxicol. Oct 18;23(10):I586-95, 2010.

Pavón Rodriguez, Manuel, "El problema de la interacción entre ciencia, tecnología, y sociedad. Una consideración crítica del campo de la CTS", Argumentos de razón técnica, NI, 1998.

Pérez Matilde, "Permisos para sembrar soja transgénica: desaparecieron hectáreas de selva virgen", La Jornada, 6 de octubre de 2015. Disponible en http://www.jornada.unam.mx/20I5//0/06/sociedad/032n2soc

Pfeiffer, María Luisa, El espacio de la desmesura. Una aproximación bioética a la moral, Antropofagia, Buenos Aires, $20 \mid 4$, en prensa.

Transgénicos. Un destino tecnológico para América Latina, (editora), Ed. Suarez, Mar del Plata, 2002.

"El deber moral de los estados y ciudadanos de preservar el mundo", Bioética, Conselho Federal de Medicina, Brasil, 2014; 22 (2), ISSN I983-8042/ 19838034: 203-2I2 http://revistabioetica.cfm.org.br/index. php/revista_bioetica/article/view/910/1035

Prigogine, Illya, La Nueva Alianza, Alianza Ed, .Madrid, 1983.

Pryme, lan F. and Lembcke, Rolf, "In Vivo Studies on Possible Health Consequences of Genetically Modified Food and Feed-with Particular Regard to Ingredients Consisting of Genetically Modified Plant", Materials Nutrition and Health, vol. 17, I: 1-8, January 2003.

Relyea, R. A.. "The lethal impacts of Roundup and predatory stress on six species of North American tadpoles." Arch. Environ. Contam. Toxicol. 48: 35I-357, 2005;. 
Ribeiro, Silvia, "Guerra sucia contra los cultivos de maíz", La Jornada, 22-8-20 I5., disponible en http://www.jornada. unam.mx/20I5/08/22/opinion/025al eco

Rifkin, Jeremy, La era del acceso. La revolución de la nueva economía, Paidos Ibérica, México, 2000.

Sábato, E., Hombres y engranajes, Emece, Buenos Aires, 1970, pág. 75.

Seraline et al, "Long term toxicity of a Roundup herbicide and a Roundup-tolerant genetically modified maize," Food and Chemical Toxicology (50) November 2012;

Shiva Ayyadurai, Prabhakar Deonikar "Do GMOs Accumulate Formaldehyde and Disrupt Molecular Systems Equilibria? Systems Biology May Provide Answers", Agricultural Sciences, Vol.6 No.7, July I0, 20 I 5. Disponible en http://www.scirp.org/journal/as/

Telam especiales, Soja y poder económico, 20I4, disponible en http://www.telam.com.ar/informes-especiales/Isoja-y-poder-economico/2-el-negocio

UPOV, Convenio, 1991, disponible en: http//www.upov.int/upovlex/es/conventions/ /99 |/act I 99 |.html

Winner, Langdon, "Do Artifacts have Politics?" en Mackenzie, D. et al (eds), The Social Shaping of Technology, Open University Press, Philadelphia, 1985.

Zamora, Alfredo, "La siembra de semillas modificadas genéticamente acumula 19 años de adopción continuada a nivel mundial", Fundación Antama, 28-1-20I5, disponible en http://fundacion-antama.org/informe-isaaacifras-mundiales-cultivos-transgenicos-20 I 4 / 